\title{
Climate Change and Coastal Floods: The Susceptibility of Coastal Areas of Nigeria
}

\author{
Adeyeri OE ${ }^{1 *}$, Ishola $\mathrm{KA}^{2}$ and Okogbue $\mathrm{EC}^{2}$ \\ ${ }^{1}$ Abomey-Calavi Laboratory, Abomey-Calavi, Republic of Benin \\ ${ }^{2}$ Deparment of Meteorology and Climate Science, Federal University of Technology, Akure, Nigeria
}

\begin{abstract}
The pressures caused by anthropogenic activities such as housing development and road construction, oil and gas exploration, economic development and demographic changes, have partly fuelled several environmental challenges faced in the coastal areas of Nigeria. One of these challenges is the flood events which have recently caused damage of properties and loss of lives in the areas. This study examines and predicts the susceptibility of the coastal region of Nigeria to flood hazard in a changing climate using geo-spatial techniques. Topographic maps and Moderateresolution imaging spectroradiometer (MODIS) image of 2015 were processed, digitized, interpolated, classified and overlaid using the suitable algorithms. The MODIS imagery was classified into suitable land cover classes using the supervised maximum likelihood scheme. The 3D-analyst module was used to generate the Hydrological Digital Elevation Model (HDEM), Triangulated Irregular Network (TIN), and flood risk map of the study area. The flood risk map was classified into high, medium, low, and no risk zones. Results showed that, areas lying along the banks of Guinea coast are highly susceptible to flood hazards with the degree of susceptibility decreasing towards the North and eastern part of the area. These areas are classified as swamps (water-log) with low water retention which gives rise to high susceptibility of coastal flood hazards. The study discovered that the flood risk map can be used as an effective tool for precautionary measures, early warning systems, and consequently reduce the damages that could be caused by flood events.
\end{abstract}

Keywords: Flood risk; HDEM; Land-cover; TIN

\section{Introduction}

The intensity, frequency, and extent of impact of natural disasters in the environment have been major concerns in many nations due to their increase in recent decades. The occurrence of these disasters has majorly been attributed to environmental degradation, such as the unfriendly responses to the natural environment that bring about deforestation, intensified land use, and population growth. Flooding is one of the natural disasters and a principal agent of environmental degradation. This event may occur if the existing surface water drainage systems and watercourses are unable to cope with the resulting increase in surface water runoff or overflow of a large volume of water over dry land [1]. The current future predictions of an increase in both the frequency of storms and in the intensity of rainfall due to climate change will possibly increase the flood events. Moreover, coastal flood is any overland flow of water over the areas along the river/ocean banks sufficient enough to cause significant damage to lives and properties. This event occurs due to the thermal expansion of the ocean and melting of ice, which in turn result in sea level rise and inundation of sea water to coastal lands. This environmental hazard regularly claims over 20,000 lives per year and adversely affects around 75 million people worldwide. Studies have reported that, floods caused about one third of all deaths, one third of all injuries and one third of all damages from natural disasters. In Nigeria, coastal flooding occurs in the low-lying belt of mangrove and fresh water swamps along the Gulf of Guinea and with a close proximity to the Atlantic Ocean [2,3]. The pattern of the impacts of flooding in Nigeria is similar with the rest of the world. Earlier studies have shown that this event has forced millions of people out of their homes, destroyed businesses, polluted water resources and increased the risk of sickness and diseases in the area. Studies noted that flood accounts for the highest occurring natural hazards, with great consequences on the life and property. Moreover, the need for continual monitoring and prediction of flood occurrence, especially in the susceptible areas, cannot be ruled out owing to the predicted rise in the mechanisms driving the changing climate. For the purpose of mitigation and preparedness, several approaches have been devised to assessing the risk and vulnerability of flood event over Nigeria. Some of these techniques include but are not limited to the use of meteorological parameters; Hydrological parameters; socio-economic factors; combination of hydro meteorological and socio-economic factors and Remote Sensing and Geographical Information System $[4,5]$. However, the use of Remote Sensing and GIS to map flood events are still limited to sufficiently measure the intensity, frequency, and extent of flood and its impacts. Studies revealed that the approach based on the Remote Sensing and Geographical Information System (GIS) techniques holds a lot of promises as they are capable of combining all the known techniques and parameters of predicting flood risk $[6,7]$. This was confirmed by studies which reported that this GIS technique is necessary to improve the flood risk analysis in the country. Thus, the studies encouraged the use of GIS in risk assessment of flooding due to its capability of integrating the geomorphological, hydrological, meteorological and socio-economic variables [8-10].

\section{Materials and Methods}

\section{Sampling site}

The study area is the coastal region of Nigeria due to their lowlying relief and close proximity to the Atlantic Ocean. The area is

*Corresponding author: Adeyeri OE, Abomey-Calavi Laboratory, AbomeyCalavi, Republic of Benin, Tel:+204-226-2575; E-mail:cyndyfem@gmail.com

Received May 25, 2017; Accepted June 22, 2017; Published June 30, 2017

Citation: Adeyeri OE, Ishola KA, Okogbue EC (2017) Climate Change and Coastal Floods: The Susceptibility of Coastal Areas of Nigeria. J Coast Zone Manag 20: 443. doi: 10.4172/2473-3350.1000443

Copyright: ( 2017 Adeyeri OE, et al. This is an open-access article distributed under the terms of the Creative Commons Attribution License, which permits unrestricted use, distribution, and reproduction in any medium, provided the original author and source are credited. 
geographically located between latitude $4^{\circ} \mathrm{N}-8^{\circ} \mathrm{N}$ and longitude $3^{\circ} \mathrm{E}-9^{\circ} \mathrm{E}$ (Figure 1).

The annual total rainfall of the area is above $1500 \mathrm{~mm}$ and temperature ranges from $21^{\circ} \mathrm{C}-29^{\circ} \mathrm{C}$. The Moderate resolution Imaging Spectroradiometer (MODIS) data of 2015 and topography map of the area were used in this study [11]. The MODIS imageries served as the primary data used in generating the land use/land cover maps of the study area (Figure 2) based on the widely used maximum likelihood classification scheme. The generated land cover types, which include the water body, thick vegetation, highlands, bare surface, swamps, short grasses, built-up area, and light vegetation, were based on the prior knowledge of the distribution of the surface features. The topography map was geo-referenced, digitized and interpolated into raster to create an adjusted Digital Elevation Model (DEM) which is the Hydrological Digital Elevation Model (HDEM) at 50m based on the Spatial Analyst module, and the Triangulated Irregular Network (TIN) based on the 3D Analyst module algorithm [6]. The stream ordering follows after Strahler studies. There are three categories at which streams can be grouped according to their orders; headwaters (Stream order 1 to 3 ), medium- sized streams (Stream order 4 to 6) and larger rivers (Stream order greater than 6). Stream order is also an important part of the River Continuum Concept [12-15]. The River Continuum Concept is a model used to determine the biotic community expected in a stream, based on the size of the stream itself. River Continuum Concept models the changes that might take place in an aquatic ecosystem as water travels from headwater streams to larger rivers. As streams flow down through a watershed, their size increases and the influence of the surrounding forest decreases. The river continuum concept provides predictions of the ways in which biological communities might change in response to such habitat differences [16,17].

To analyse the areas susceptible to flood event in the study area, the spatial database that considers flood-related factors such as the flow characteristics, buffer zones, and population, vulnerability and stream

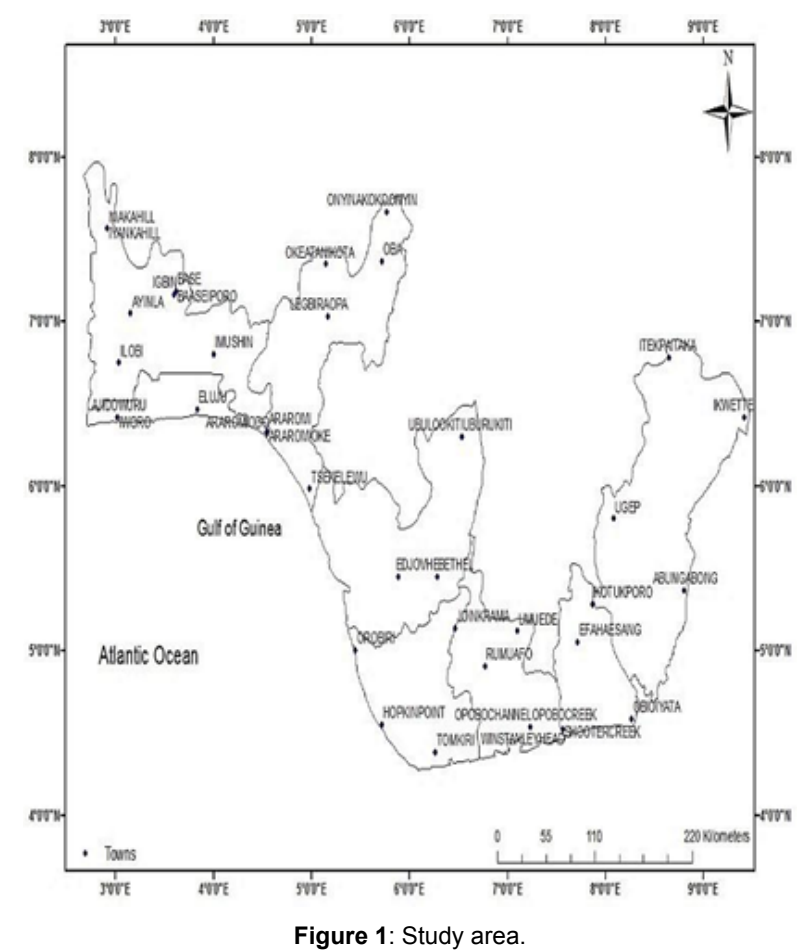

parameters was designed and created using Arc-Hydro tools. The flood risk map was then developed by overlaying the required parameters and classified the area into four basic risk zones based on studies which are the high, medium, low, and no risk zones $[18,19]$.

\section{Results and Discussion}

The classified MODIS satellite imagery of the coastal area of Nigeria is presented in Figure 2. The spatial extent of the classified land cover types revealed that the swamps and water body were found majorly along the banks of Guinea Gulf. Significantly, the highlands were observed over some northern parts of Ondo and Ogun States. A large proportion of the coastal areas are predominantly covered with different vegetation types and with fewer built-up and bare surface areas. The DEM reconditioning in Figure 3 presents the classified spatial distribution of the height above mean sea level. The areas south of Lagos, Ondo, Delta, and few areas in Bayelsa and Rivers geographically located between latitude $4^{\circ} \mathrm{N}$ and $7^{\circ} \mathrm{N}$ and longitude $3^{\circ} \mathrm{E}$ and $6^{\circ} \mathrm{E}$, and majorly classified as swamps and water body along the bank of Gulf of Guinea were observed to lie at low elevation between 0 and $90 \mathrm{~m}$. The HDEM also showed that the areas classified as highlands lie at elevation above $300 \mathrm{~m}$. These imply that the HDEM classified low-lying and high ground areas are most and not vulnerable to flooding respectively. The areas observed at HDEM between 90 and $300 \mathrm{~m}$ can just be or less vulnerable to flood event. These findings are consistent with the study which reported most vulnerable areas of flooding at Digital Terrain Model (DTM) between 105 and $172 \mathrm{~m}$, while above $172 \mathrm{~m}$ can just be or less vulnerable to flooding.

The triangulated make of the HDEM (Figure 4) shows similar spatial distribution with the HDEM. The TIN revealed that virtually all the coastal areas of the country are vulnerable with the TIN elevation value between 0 and $200 \mathrm{~m}$ but the magnitude and extent of vulnerability can be attributed to other flood-related factors rather than only the HDEM or TIN.

It is worthy to note that most streams in these coastal areas are of the order of one (Figure 5). First-order streams are streams that carry water throughout the year (Perennial streams). They have no permanently flowing tributaries; this means no other streams feed them. As water travels from headwater streams toward the mouths of mighty rivers, the width, depth, and velocity of the waterways gradually increase. The amount of water they discharge also increases. These characteristics dictate the types of aquatic organisms that can inhabit the streams.

The classified flood risk zones in the coastal area using $50 \mathrm{~m}$ buffer zone are shown in Figure 6. It is observed that there are variations in the degree of susceptibility to flooding in the area. The areas observed as the high risk zones are mostly Lagos, Ogun waterside, Warri, Ilaje, Ese Odo, Burutu, Bakassi, and Akpabuyo which are closest to the Atlantic Ocean.

Flooding is experienced in most areas in this classification annually. The areas are characterized by very low relief as discussed earlier and water logged soils with a very low retention capacity. These areas lie directly on the path of monsoon flow thus, most of the flood events experienced over these areas may be attributed to the surge of moisture flux from the Atlantic Ocean that brings about heavy downpour of rainfall more than what the drainage systems and watercourses can accommodate, resulting in an increase in the surface sedimentation. Studies has reported that high flood susceptibility areas in Makurdi are mostly low grounds, water-logged soils, and closest to River Benue 


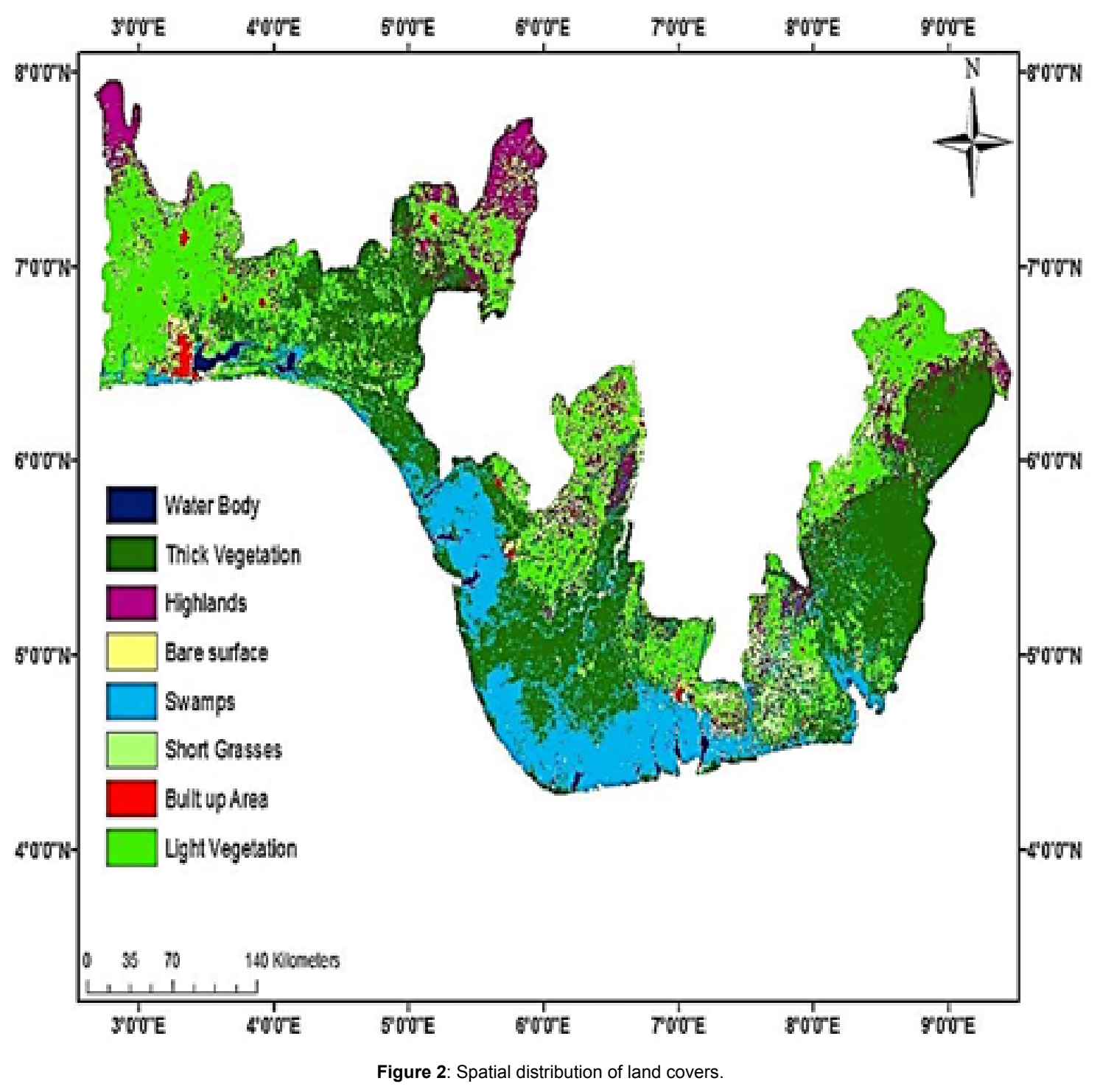

which is consistent with the findings of this study. The areas marked as medium risk include, Southern Ijaw, Ndokwa west, Ika, Aniocha, virtually all areas in Akwa Ibom, Biase, Yakurr, Ikom, Ogoja, and Boki. These areas mainly constitute different vegetation types with little low relief. These areas still have tendency to be flooded in the event of heavy downpour that may cause the nearby water to overflow its banks. Figure 6 also revealed the low and no risk zones are Idanre, Akure, Akoko, Owo, Emuoha, Degema, Okrika, Ikwerre, Etung, Obaniku and Boki due to their high reliefs.

The spatial distribution of the flood risk zones of coastal region of Nigeria has shown that the region is highly susceptible to flooding. This is due to the fact that a large proportion of the area was attributed to some degree of risk. Therefore, it is necessary to reduce or steer away development from the delineated potentially high susceptible areas to low susceptibility areas.

\section{Conclusion}

The findings in this study have indicated that the areas lying on the path of storm surge from the Atlantic Ocean and with low reliefs are highly susceptible to flooding, with the degree of susceptibility decreasing towards the North. Therefore, the recent and predicted climate change could result in unpredictability and intensification of the tropical cyclone, storm surge and sea level rise due to thermal expansion of the oceans. This will deepens the flood waters and potentially impact the greater land areas along the coast. However, the climate change impact of coastal flooding are highly uncertain and depend critically on adequate coastal defences and disaster preparedness. The capability of GIS tool in delineating the flood susceptibility areas in the coastal region of Nigeria has proven consistent, reliable, and can be adopted for decision making in terms of flood forecasting, emergency preparedness and response, and consequently reduce the damages caused by flood hazards in the area. The study therefore suggests integrating hydrological models with GIS to simulating future scenario of flood occurrence which will also help in early warning system and management strategies. 

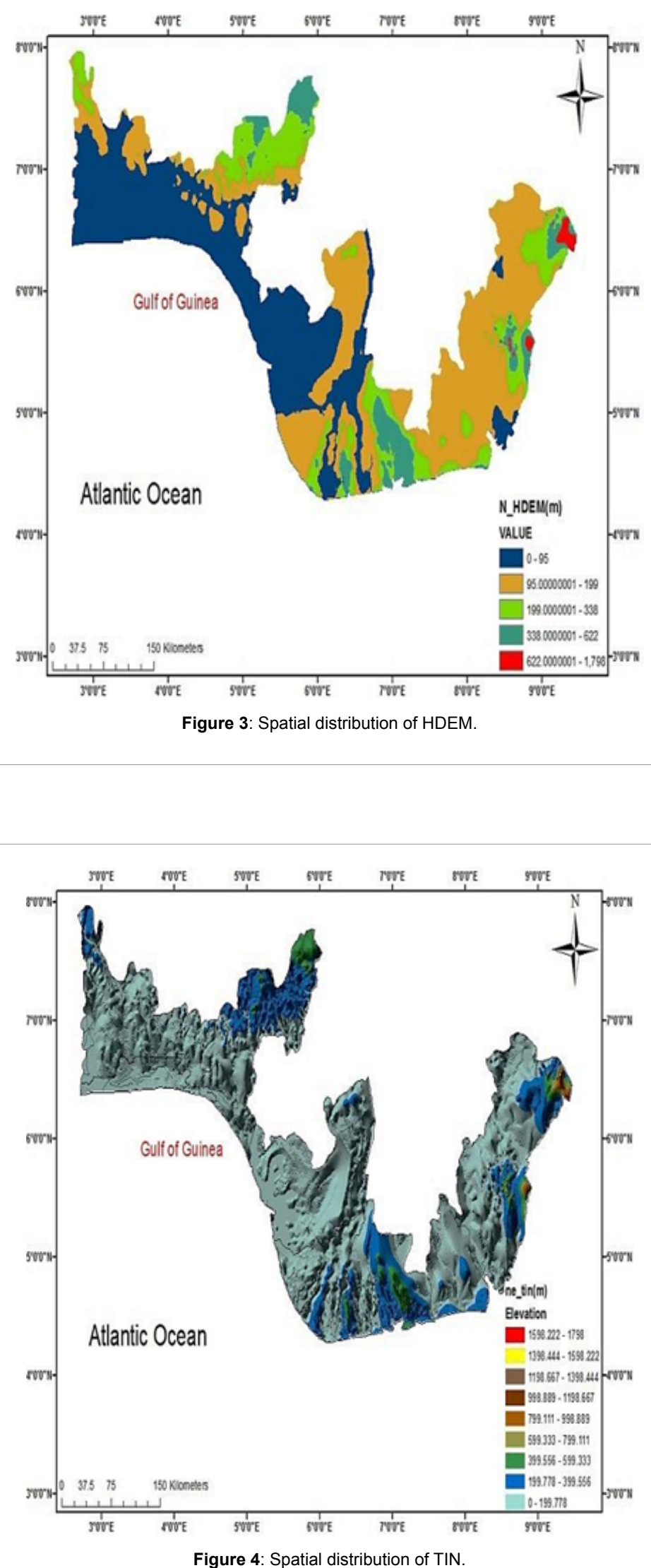

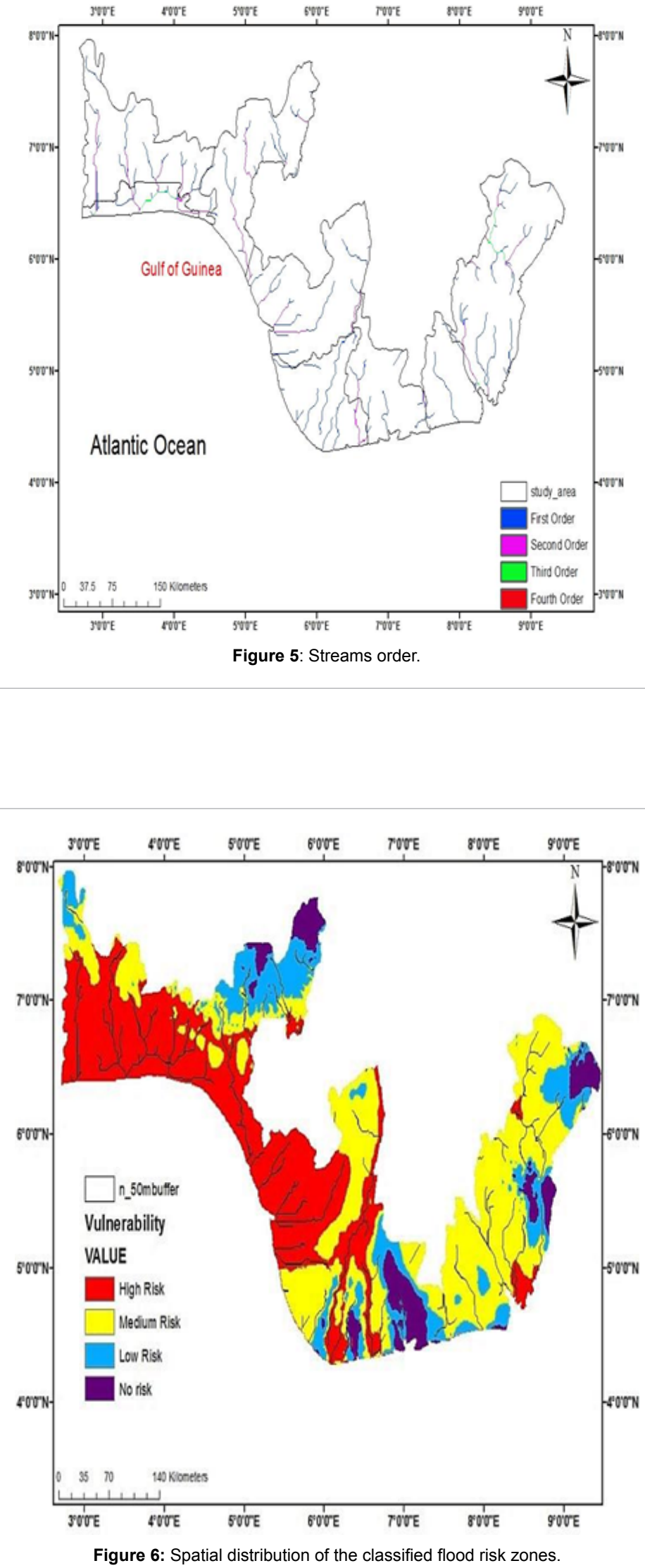
Citation: Adeyeri OE, Ishola KA, Okogbue EC (2017) Climate Change and Coastal Floods: The Susceptibility of Coastal Areas of Nigeria. J Coast Zone Manag 20: 443. doi: 10.4172/2473-3350.1000443

Page 6 of 6

\section{References}

1. Abah RC (2013) An application of geographic information system in mapping flood risk zones in a north central city in Nigeria. Int J Water Resources Environ Eng 7: 365-377.

2. Abams TK (1995) State of erosion and flooding in the Niger Delta Report prepared for the World Bank.

3. Abams TKS (1995) The 1988 floods in Niger Delta, the case of Kiama. In proceedings of the International Workshop in Natural and Manmade Hazards in Africa. NMGS Publication 4: 119-130.

4. Adefisan EA, Abdulkareem SB, Orimoloye IR (2015) Application of ge-spatial technology in identifying areas vulnerable to flooding in Ibadan metropolis. J Environ Ear Sci 5: 156-166.

5. Adejuwon GA, Aina WJ (2014) Emergency preparedness and response to Ibadan flood disaster. Implications for well-being. Mediterranean J Soc Sci 5 : 8-12.

6. Aderogba KA (2012) Qualitative studies of recent floods and sustainable growth and development of cities and towns in Nigeria. Int J Basic App Sci 1: 200-216.

7. Askew AJ (1999) Water in the International Decade for Natural Disaster Reduction. Destructive Water: Water-caused Natural Disasters, their Abatement and Control 3: 230-239.

8. Edward-Adebiyi R (1997) The story of Ogunpa. The Guardian 17: 5-20.

9. Durotoye B (2000) Geo-Environmental constraints in the development of Niger
Delta area of Nigeria. In: Akinjide Osuntokun (ed.), Environmental Problems in Nigeria. Fredrick Ebert Foundation, Lagos, Nigera.

10. Haruna GI, Abubakar I, Abdullahi A, Saminu F, Bayang, et al. (2013) Hydrological modelling of the impact of climate change on a tropical perennia river flooding. Int J Eng Sci 3: 30-35.

11. Komolafe AA, Adegboyega SA, Akinluyi FO (2015) A review of flood risk analysis in Nigeria. American J Environmental Sciences 11: 157-166.

12. Lee S, Pradhan B (2007) Landslide hazard mapping at Selangor, Malaysia using frequency ratio and logistic regression models. Landslides 4: 33-41.

13. Nwaubani C (1991) Ogunpa river leaves bitter aftertaste in Tragic course through Abeokuta. The Guardian 21: 9-18.

14. Ologunorisa ET (2004) An assessment of flood vulnerability zones in the Niger Delta Nigeria. Environ J Environ Stud 61: 65-70.

15. Ologunorisa TE, Abawua MJ (2005) Flood risk assessment: A review. J App Sci Environ Mgt 9: 57-63.

16. Oriola EO (1994) Strategies for combating urban flooding in a developing nation: A case study from Ondo, Nigeria. The Environmentalist 14: 57-62.

17. Sami K, Mohsen BA, Afef K, Fouad Z (2013) Hydrological modelling using GIS for mapping flood zones and degree flood risk in Zeuss-Koutine Basin (South of Tunisia). J Environ Pro 4: 1409-1422.

18. Smith K (1996) Environmental hazards. Routledge, London.

19. Strahler AN (1952) Hypsometric (area-altitude) analysis of erosional topology. Geological Society of America Bulletin 63: 1117-1142. 